\title{
Pemanfaatan Tanaman Hidroponik Mengandung Zat Besi Tinggi di Pondok Pesantren Nurul Amin
}

\author{
Kresna Febriyanto ${ }^{1}$, Vira Selvi Yonika ${ }^{2}$, Wahdaniah ${ }^{3}$, Haikal Rahman \\ Adilara Erdin ${ }^{4}$, Muhammad Rizan $^{5}$, Ralda Yanti Syahdan ${ }^{6}$, Ariza Adela ${ }^{7}$, \\ Mardiana $^{8}$ \\ ${ }^{12345678}$ Universitas Muhammadiyah Kalimantan Timur \\ Email : kresna.kesmas@umkt.ac.id¹, virasalosso59@gmail.com², wahdania10h@ \\ gmail.com ${ }^{3}$, haykel11998@gmail.com ${ }^{4}$, muhammadrizan0628@gamil.com ${ }^{5}$, \\ raldayantis@gmail.com ${ }^{6}$, arizaadela30@gmail.com ${ }^{7}$, \\ dianaadjiwiyono29@gmail.com ${ }^{8}$
}

\begin{abstract}
ABSTRAK
Masa remaja merupakan masa pertumbuhan dan perkembangan, remaja putri yang paling banyak mengalami kekurangan zat-zat gizi terutama makanan yang mengandung zat besi tinggi dikarenakan telah memasuki masa menstruasi. Kelompok masyarakat yang rentan terhadap anemia adalah santri pondok pesantren karena masalah pola makan yang dapat mempengaruhi status gizi santriah tersebut. Prevalensi anemia sebesar 25,5\%. Prevalensi anemia di Indonesia sebesar 21,7\% proporsi pada perempuan sebesar $23,9 \%$ dan sisanya laki-laki. Kegiatan pemberdayaan masyarakat dilaksanakan dengan tujuan meningkatkan kesehatan santriwati dengan pemanfaat tanaman hidroponik mengandung zat besi tinggi sebagai salah satu alternatif dalam mengatasi penyakit anemia di Pondok Pesantren Salafiyah Nurul Amin J1. Kurnia Makmur RT.23 Kel. Harapan Baru Kec. Loa Janan Ilir Samarinda Seberang. Metode pemberdayaan masyarakat ini yaitu pelatihan kepada 21 orang santriwati kader Alarm Kesehatan dalam pembuatan tanaman hidroponik, perawatan hingga pengelolaan terkait hasil dari tanaman yang telah di tanam. Pelatihan penanaman hidroponik dengan sistem wick dilaksanakan pada tanggal 10 November 2019 selanjutnya diimplementasikan kembali oleh kader Alarm Kesehatan kepada santriah dan selanjutnya untuk pengelolaan dan perawatan tanaman hidroponik dilaksanakan setiap harinya oleh para santriwati. Kader Alarm Kesehatan melakukan pemantauan santriwati dalam pemanfaatan tanaman hidroponik yang mengandung zat besi tinggi dengan memanfaatkan barang bekas berupa botol plastik ukuran $1600 \mathrm{ml}$.
\end{abstract}

Kata Kunci: hidroponik; kader alarm kesehatan; pondok pesantren.

\section{Utilization of Hydroponic Plants with High Iron in Pondok Pesantren Nurul Amin}

\begin{abstract}
Adolescence is a period of growth and development, girl teenage who experience the most nutritional deficiencies that contain high iron because they have menstruation. Community groups that are prone to anemia are boarding school students because of eating patterns that can affect the nutritional status of these students. The prevalence of anemia is $25.5 \%$. The prevalence of anemia in Indonesia is $21.7 \%$ the proportion in women is $23.9 \%$ and the rest are men. Community empowerment activities are carried out with the aim of improved the health status of students by utilizing hydroponic plants containing iron as an alternative in overcoming anemia in the Salafiyah Nurul Amin Islamic Boarding School Jl. Kurnia Makmur RT.23 Kel. Harapan Baru Kec. Loa Janan
\end{abstract}


Ilir Samarinda Seberang. This community empowerment method is training for 21 cadre students. Health alarm in making hydroponic plants, treatment for management related to the results of plants that have been planted. The hydroponic planting training with the wick system was held on November 10, 2019 and then re-implemented by the Health Alarm cadre for students and the management and care of hydroponic plants carried out at any time by the students. Health Alarm Cadre provides students in the use of hydroponic plants that contain high substances by used containing $1600 \mathrm{ml}$ plastic bottles.

Keywords: hydroponics; health alarm cadres; islamic boarding schools.

\section{PENDAHULUAN}

Masa remaja merupakan masa pertumbuhan dan perkembangan baik secara, fisik, mental, dan aktivitas sehingga menyebabkan kebutuhan makanan yang mengandung zat-zat gizi menjadi lebih besar. Remaja putri merupakan remaja yang paling banyak mengalami kekurangan zatzat gizi dalam konsumsi makanan sehari-harinya. Kekurangan zat besi merupakan hal utama sebagai penyebab dari anemia secara global, serta hal lain yang merupakan kekurangan gizi (seperti folat, vitamin B12 dan vitamin A), akut dan peradangan kronis, parasit infeksi dapat menyebabkan anemia. Remaja putri merupakan salah satu kelompok yang rawan menderita anemia, karena pada masa itu mereka mengalami menstruasi serta pengetahuan mereka yang kurang tentang anemia. Anemia merupakan masalah gizi yang paling umum di dunia yang terutama disebabkan karena defisiensi besi. Prevalensi anemia remaja $27 \%$ di negara-negara berkembang dan $6 \%$ di negara maju. Prevalensi tertinggi yaitu terhadap kalangan anak-anak dan Wanita Usia Subur (WUS) terkhusus pada wanita hamil. Anemia sangat tinggi berkisar antra 80\% - 90\% pada anak-anak prasekolah, remaja, ibu hamil, dan menyusui. Menurut WHO apabila prevalensi anemia $>40 \%$ termasuk ke dalam kategori berat (Suryani, Hafiani, \& Junita, 2015).

Pada negara berkembang diperkirakan lebih dari $30 \%$ penduduk dunia atau 1500 juta orang menderita anemia dan sebagian besar tinggal di daerah tropik. Defisiensi zat besi merupakan masalah gizi yang paling lazim di dunia dan menjangkiti lebih dari 600 juta manusia. Prevalensi anemia secara global adalah sekitar 51\%. Prevalensi untuk balita sekitar $43 \%$, anak usia sekolah sebesar $37 \%$, pria dewasa hanya sebesar $18 \%$, dan wanita tidak hamil sebesar $35 \%$. Di Indonesia anemia gizi masih merupakan salah satu masalah gizi yang utama, di samping tiga masalah gizi lainnya yaitu kurang kalori protein, defisiensi vitamin A dan gondok endemik (Shariff \& Akbar, 2018).

Berdasarkan data Riskesdas (2013), prevalensi anemia sebesar $25,5 \%$ dengan tingkat prevalensi pada status gizi baik sebesar 16\% dan prevalensi anemia pada gizi lebih sebesar 9,5\%. Prevalensi nasional anemia di Indonesia dilaporkan bahwa angka kejadian sebesar 21,7\%. Proporsi kejadian anemia di Indonesia menurut karakteristik jenis kelamin, yaitu perempuan sebesar $23,9 \%$ lebih dominan dibanding laki-laki sebesar 


\section{8,4\% (KEMENKES RI, 2013).}

Remaja putri merupakan salah satu kelompok yang rawan menderita anemia. Berdasarkan kelompok umur, penderita anemia berumur 5-14 tahun sebesar 26,4\% dan pada kelompok umur 15-24 tahun sebesar 18,4\%. Dari semua kelompok umur tersebut, wanita mempunyai resiko paling tinggi untuk menderita anemia terutama remaja putri. Salah satu kelompok masyarakat yang rentan terhadap anemia adalah santri pondok pesantren. Masalah pola makan sering dijumpai sehingga dapat mempengaruhi status gizi santriwati tersebut. Kejadian anemia dapat dipengaruhi oleh menstruasi yang dialami remaja putri secara normal setiap bulannya. Ini disebabkan karena volume darah haid yang keluar ratarata mencapai $35-50 \mathrm{ml}$, pada periode haid tersebut wanita kehilangan $30 \mathrm{mg}$ besi. Banyaknya darah yang hilang menyebabkan perempuan yang tengah haid mengalami lemas, lesu hingga berkunang-kunang ini adalah salah satu tanda-tanda anemia defesiensi besi. Hal ini dapat diperparah jika siklus haid memanjang karena banyaknya volume darah yang keluar (Shariff \& Akbar, 2018).

Anemia menyebabkan darah tidak cukupuntukmengikat danmengangkut oksigen dari paru-paru ke seluruh tubuh sehingga akan mengakibatkan sulitnya untuk berkonsentrasi yang dapat mengakibatkan prestasi belajar menurun, daya tahan fisik rendah sehingga menjadi mudah lelah, aktivitas fisik menurun, serta daya tahan tubuh rendah yang mengakibatkan mudah sakit. Pada umumnya remaja putri memiliki karakteristik kebiasaan makan yang tidak sehat seperti tidak sarapan pagi, malas minum air putih, diet tidak sehat karena ingin langsing (mengabaikan sumber karbohidrat, protein, lemak, vitamin dan mineral), kebiasaan mengemil makanan rendah gizi serta makan makanan siap saji sehingga remaja tidak mampu memenuhi keanekaragaman zat makanan yang dibutuhkan tubuh untuk proses sintesis pembentukan hemoglobin $(\mathrm{Hb})$ bila ini terjadi pada waktu lama dapat menyebabkan kadar $\mathrm{Hb}$ terus berkurang dan mengakibatkan anemia (Suryani, Hafiani, \& Junita, 2015). Pencegahan dilaksanakan melalui tindak lanjut dini serta pengelolaan anemia yang tepat dan minum tablet Fe untuk menambah pembentukan sel darah merah/Hemoglobin ( $\mathrm{Hb})$ (Wulandari dan Fitriasih, 2014).

Pemberdayaan masyarakat adalah suatu proses memfasilitasi warga masyarakat secara bersamasama pada suatu tujuan yang secara kolektif dapat mengidentifikasi sasaran, mengumpulkan sumber daya, mengerahkan suatu kampanye aksi, dan dapat membantu menyusun kembali kekuatan dalam komunitas. (Purbantara \& Mujianto, 2019).

Upaya untuk meningkatkan status derajat kesehatan masyarakat terutama remaja dengan menggerakan serta memberdayakan remaja putri/santriwati untuk hidup sehat, meningkatkan akses santriwati terhadap pelayanan kesehatan yang berkualitas, meningkatkan sistem surveilans, monitoring dan informasi 
kesehatan, serta meningkatkan pembiayaan kesehatan. Salah satu program pemberdayaan masyarakat untuk mengurangi penyakit anemia yang adadi PondokPesantren Salafiyah Nurul Amin, Kelurahan Harapan Baru yaitu dengan pemanfaatan tanaman hidroponik.

Tanaman Hidroponik adalah tanaman yang ditanam dengan pemanfaatan air tanpa menggunakan tanah sebagai media tanam, dengan pemenuhan kebutuhan nutrisi tanaman untuk bisa tumbuh. Hal yang paling penting untuk tanaman hidroponik adalah pemenuhan nutrisi tanaman yang berbentuk larutan. Cara penanaman hidroponik sangat cocok untuk tempat yang pasokan airnya kurang. Ada beberapa tipe sistem hidroponik salah satunya yaitu wick system (sistem sumbu) (Tallei, Rumengan, \& Adam, 2017). Pada kelebihan hidroponik sistem sumbu yaitu kombinasi kedua sistem hidroponik dengan larutan nutrisi dapat tersirkulasi serta volume larutan hara yang dibutuhkan lebih rendah. Tanaman tumbuh dengan optimal umur panen menjadi lebih singkat dengan penggunaan nutrisi yang efisien (Kamila, Dewanti, \& Soedrajad, 2017).

Pembuatan tanaman hidroponik ini menggunakan botol plastik bekas. Indonesia merupakan negara penyumbang sampah plastik terbesar nomor 2 di dunia. Maka untuk mengurangi limbah botol plastik digunakan sebagai bahan utama dalam pembuatan tanaman hidroponik, dengan harganya yang murah dan mudah didapatkan dan untuk mengurangi penggunaan plastik yang susah diurai dan membutuhkan waktu seribu tahun. (Haifaturrahmah, Nizaar, \& Mas'ad 2017).

Anemia merupakan salah satu dari 10 penyakit yang terdapat di Pondok Pesantren Salafiyah Nurul Amin J1. Kurnia Makmur RT.23 Kel. Harapan Baru Kec. Loa Janan Ilir Samarinda Seberang dan merupakan penyakit tertinggi yang terjadi di Pondok Pesantren itu, mayoritas dari penderita penyakit anemia yaitu santriwati/ remaja putri. Hasil observasi yang telah dilakukan ditemukan data di lapangan menunjukkan bahwa di Pondok Pesantren Salafiyah Nurul Amin, Kelurahan Harapan Baru terdapat 68 orang dengan sejumlah gejala 44 kasus anemia. Hasil observasi yang kami dapat bahwa satu orang santriwati di Pondok Pesantren Nurul Amin, Keluarahan Harapan Baru mengalami kasus anemia berat. Seringnya kebiasaan begadang yang dilakukan para santriwati mengakibatkan tingginya penyakit anemia.

Dari data yang telah diuraikan diatas maka perlu dilaksanakan pemberdayaan masyarakat sebagai bentuk pengabdian dalam peningkatan kehidupan masyarakat. Selain itu, untuk mewujudkan kesejahteraan dan membantu para penghuni Pondok Pesantren Salafiyah Nurul Amin, Kelurahan Harapan Baru dan para santriah dalam menyelesaikan permasalahan kesehatan secara mandiri. Kegiatan pemberdayaan masyarakat dilaksanakan dengan 
tujuanmeningkatkan derajatkesehatan para santriah dengan pemanfaatan tanaman hidroponik mengandung zat besi tinggi sebagai salah satu alternatif dalam mengatasi penyakit anemia di Pondok Pesantren Salafiyah Nurul Amin J1. Kurnia Makmur RT.23 Kel. Harapan Baru Kec. Loa Janan Ilir Samarinda Seberang.

\section{METODE PENELITIAN}

Metode yang digunakan dalam pelaksanaan kegiatan pemberdayaan masyarakat ini adalah pelatihan pemanfaatan tanaman hidroponik yang mengandung zat besi tinggi, melakukan tes fisik dengan menggunakan instrumen alat tensi untuk mengukur tekanan darah seseorang, serta menggunakan lembar observasi untuk melihat keadaan fisik para santriwati terkait dengan ciri-ciri penderitaanemiasepertikelopakdalam mata yang pucat, badan yang lesu, tubuh pucat hingga ciri-ciri lainnya. Ini dilakukan kepada para santriwati di Pondok Pesantren Salafiyah Nurul Amin Jl. Kurnia Makmur RT.23 Kel. Harapan Baru Kec. Loa Janan Ilir Samarinda Seberang. Pelatihan pemanfaatan tanaman hidroponik dilaksanakan pada bulan November 2019 serta penerapan selanjutnya dapat dilanjutkan oleh kader Alarm Kesehatan yang telah diberdayakan pada santriah Pondok Pesantren Salafiyah Nurul Amin sebanyak 21 orang yang dilaksanakan setiap 1 kali seminggu.

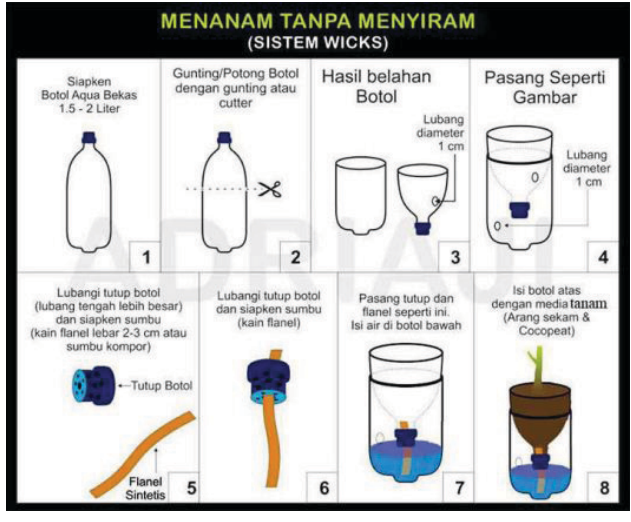

Gambar 1 Metode Pembuatan Hidroponik

\section{HASIL DAN PEMBAHASAN}

Pemberdayaan masyarakat di Pondok Pesantren Salafiyah Nurul Amin, Kelurahan Harapan Baru guna memandirikan dan memberdayakan para santriwati untuk mampu membuat dan merawat tanaman hidroponik serta mengelola hasil panen yang kemudian diolah menjadi sayur-mayur lalu dihidangkan kepada santriwati. Tanaman hidroponik yang ditanam merupakan tanaman yang mengandung zat besi tinggi sehingga baik untuk dikonsumsi.

Hasil dari kegiatan pemberdayaan masyarakat ini adalah penulis memberikan pelatihan kepada 21 Kader Alarm Kesehatan untuk menanam Tanaman Hidroponik pada tanggal 1 Desember 2019. Setelah melakukan pelatihan pembuatan tanaman hidroponik, penulis juga melakukan advokasi kepada pemilik Pondok Pesantren Salafiyah Nurul Amin. Advokasi ini dilakukan agar pengasuh dapat memantau tanaman hidroponik yang telah ditanam secara berkelanjutan.

Faktor utama penyebab anemia yang ada di Pondok Pesantren 
Salafiyah Nurul Amin, Kelurahan Harapan Baru adalah asupan zat besi yang kurang. Sekitar dua pertiga zat besi dalam tubuh terdapat dalam sel darah merah hemoglobin. Faktor lain yang berpengaruh terhadap kejadian anemia antara lain gaya hidup seperti kebiasaan sarapan pagi, sosial ekonomi dan demografi, pendidikan, jenis kelamin, umur dan wilayah. Anemia dapat menyebabkan cepat lelah, konsentrasi belajar menurun sehingga prestasi belajar rendah, menurunnya kesehatan reproduksi, perkembangan motorik, mental, kecerdasan terhambat, dan tidak tercapainya tinggi badan yang maksimal (Jaelani, Simanjuntak, \& Yuliantini, 2017).

Pemanfaatan tanaman hidroponik mengandung zat besi tinggi adalah salah satu metode untuk mengatasi masalah anemia yang ada di Pondok Pesantren Salafiyah Nurul Amin, Keluruahan Harapan Baru. Tanaman hidroponik ialah lahan budidaya pertanian tanpa menggunakan media tanah, sehingga hidroponik merupakan aktivitas pertanian yang dijalankan dengan menggunakan air sebagai medium untuk menggantikan tanah. Adapun manfaat dari penanaman dengan hidroponik ini, membuat tanaman lebih steril dan bersih, teknik hidroponik ini juga tidak membuat tanaman bergantung pada iklim sehingga meski hujan ataupunkemarau tanaman dapat tumbuh dengan baik sehingga resiko terjadinya kerusakan pada tanaman lebih sedikit.

Hasil panen denganmenggunakan tanaman hidroponik ini lebih renyah dan bergizi sebab teknik hidroponik bebas pestisida sehingga sangat sehat dikonsumsi. Hasil dari panen tanaman hidroponik tersebut dapat dikonsumsi serta dapat dokonsumsi santriwati sebagai sayur-mayur ataupun dapat dijual kepada pengasuh, pengelola Pondok Pesantren, maupun warga sekitar sehingga dapat menambah penghasilan Pondok Pesantren Salafiyah Nurul Amin, Kelurahan Harapan Baru dimana kebutuhan pangan mereka juga akan terpenuhi terutama dalam pemenuhan zat besi dan menjadi upaya mengurangi penggunaan limbah plastik untuk tidak mencemari lingkungan (Roidah, 2014).

Pelatihanpemanfaatanpembuatan tanaman hidroponik ini menggunakan botol plastik bekas. Karena, Indonesia merupakan negara penyumbang sampah plastik terbesar nomor 2 di dunia. Maka untuk mengurangi limbah botol plastik digunakan sebagai bahan utama dalam pembuatan tanaman hidroponik, dengan harganya yang murah dan mudah didapatkan dan untuk mengurangi penggunaan plastik yang susah diurai dan membutuhkan waktu seribu tahun. (Haifaturrahmah, Nizaar, \& Mas'ad 2017).

Pemberdayaaninibertujuanuntuk meningkatkan kualitas kehidupan serta derajat kesehatan para santriwati. Selain itu, untuk mewujudkan kesejahteraan dan membantu para penghuni Pondok Pesantren Salafiyah Nurul Amin, Kelurahan Harapan Baru dan santriwati menyelesaikan permasalahan kesehatan secara mandiri agar tercapainya derajat 
kesehatan masyarakat yang setinggitingginya khususnya pada santriah demi meningkatkan Usia Harapan Hidup di Indonesia.

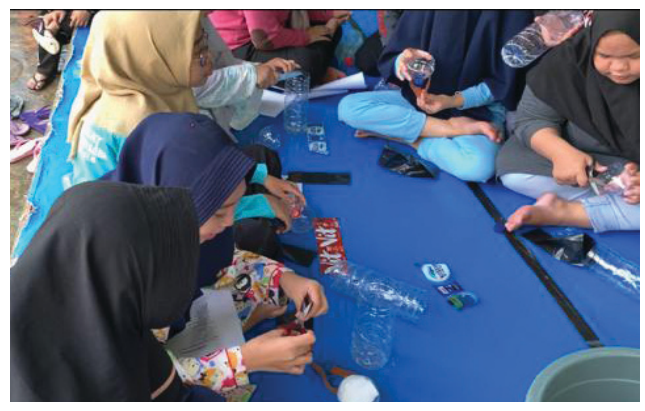

Gambar 2 Proses Pelatihan

Pembuatan Tanaman Hidroponik

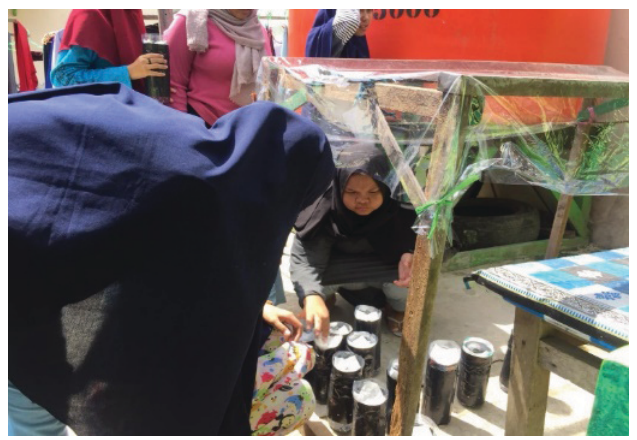

Gambar 3 Pemanfaatan Tanaman Hidroponik

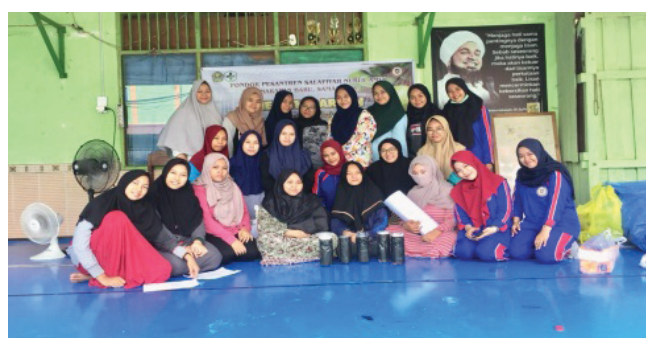

Gambar 4 Hasil Tanaman Hidroponik

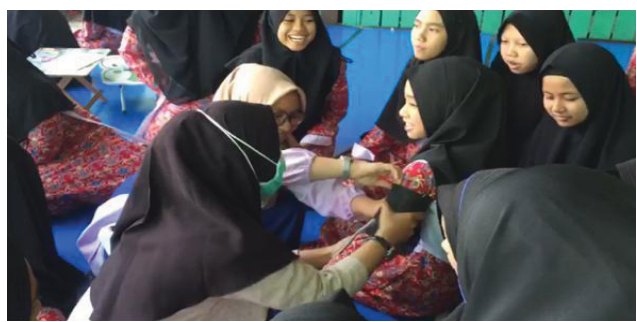

Gambar 5 Pemeriksaan Tensi Darah Santriwati

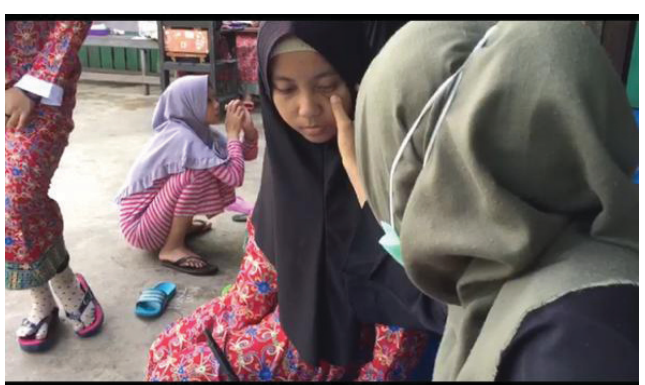

Gambar 6 Pemeriksaan Tes Fisik

\section{SIMPULAN}

Pemanfaatan tanaman hidroponik oleh santriah sebanyak 21 orang dilaksanakan di Pondok Pesantren Salafiyah Nurul Amin Jl. Kurnia Makmur RT.23 Kel. Harapan Baru Kec. Loa Janan Ilir Samarinda Seberang setiap hari yang dipantau oleh kader Alarm Kesehatan. Kegiatan ini bertujuan untuk mengatasi penyakit anemia yang terjadi pada santriah di Pondok Pesantren Salafiyah Nurul Amin, Kelurahan Harapan Baru. Pelatihan pemanfaatan pembuatan tanaman hidroponik ini menggunakan botol plastik bekas. Karena, untuk mengurangi limbah, botol plastik digunakan sebagai bahan utama dalam pembuatan tanamanhidroponik karena harganya yang murah dan mudah didapatkan serta untuk mengurangi penggunaan sampah plastik yang susah diurai dan membutuhkan waktu seribu tahun.

\section{DAFTAR PUSTAKA}

Haifaturrahmah, Nizzar, M., \& Mas'ad. (2017). Pemanfataan Botol Plastik Bekas Sebagai Media Tanam Hidroponik dalam Meningkatkan Kesadaran Siswa Sekolah Dasar Terhadap Lingkungan Sekitar. Jurnal Masyarakat Mandiri, 1, 1.

Hakimah, E. N., \& Sardanto, R. (2017). Pemberdayaan Masyarakat 
Melalui Pelatihan Hidroponik Mmebentuk Wirausawan Baru pada Perum Kuap Utara Kelurahan Ngadirejo Kota Kediri. ABDINUS, I, 75-82.

Jaelani, M., Simanjuntak, B. Y., \& Yuliantini, E. (2017, November). Faktor Risiko yang Berhubungan dengan Kejadian Anemia pada Remaja Putri. Jurnal Kesehatan, VIII, 358-368.

Kamila, S., Dewanti, P., \& Soedrajad, R. (2017). Teknologi Hidroponik Sistem Sumbu pada Produksi Selada LOLLOROSSA(Lactuca sativa L.) dengan Penambahan $\mathrm{CaCl} 2$ sebagai Nutrisi Hidroponik. Agroteknologi, XI, 96-104.

KEMENKES RI, K. K. (2013). Riset Kesehatan Dasar. Kementerian Kesehatan Republik Indonesia.

Purbantara, A., \& Mujianto. (2019). Pemberdayaan Masyrakat Desa. Kementerian Desa, Pembangunan Daerah Tetinggal dan Transmigrasi Republik Indonesia.

Roidah, I. S. (2014). Pemanfaatan Lahan dengan Menggunakan Sistem Hidroponik. Jurnal Universitas Tulungangung BONOROWO, I, 43-50.

Saturi, S. (2019, September). Daur Ulang Sampah Plastik di Idonesia Rendah.

Shariff, S. A., \& Akbar, N. (2018, Januari). Hubungan Antara Status Gizi dan Pola Menstruasi dengan Kejadian Anemia pada Mahasiswi Prodi DIII Kebidanan Universitas Muslim Indonesia. Window of Health, I, 34-39.

Suryani, D., Hafiani, R., \& Junita, R. (2015, Oktober). Analisis Pola Makan dan Anemia Gizi Besi pada Remaja Putri Kota Bengkulu. Jurnal Kesehatan Masyarakat Andalas, 10, 11-18.

Tallei, T. E., Rumengan, I. F., \& Adam, A. A. (2017). Hidroponik untuk Pemula. Manado: LPPM UNSRAT.

Purbantara, A., \& Mujianto. (2019). Pemberdayaan Masyrakat Desa. Kementerian Desa, Pembangunan Daerah Tetinggal dan Transmigrasi Republik Indonesia.

Wulandari, C. L., \& Fitriasih, Y. (2014, Agustus). Pentingnya Suplemen Tablet Besi Bagi Peningkatan Kadar Hemoglobin Pada Remaja Putri. Majalah Ilmiah Sultan Agung, LII, 133. 